\begin{tabular}{|l|l|l||}
\hline \multicolumn{2}{|c|}{ PublisherInfo } \\
\hline \hline PublisherName & $:$ & BioMed Central \\
\hline \hline PublisherLocation & $:$ & London \\
\hline \hline PublisherImprintName & $:$ & BioMed Central \\
\hline \hline
\end{tabular}

\title{
Tetraspanins in flies
}

\begin{tabular}{|l|l|l||}
\hline \multicolumn{2}{|c||}{ ArticleInfo } \\
\hline \hline ArticleID & $:$ & 4615 \\
\hline \hline ArticleDOI & $:$ & $10.1186 /$ gb-spotlight-20021021-01 \\
\hline \hline ArticleCitationID & $:$ & spotlight-20021021-01 \\
\hline \hline ArticleSequenceNumber & $:$ & 281 \\
\hline \hline ArticleCategory & $:$ & Research news \\
\hline ArticleFirstPage & $:$ & 1 \\
\hline \hline ArticleLastPage & $:$ & 2 \\
\hline \hline & $:$ & RegistrationDate : 2002-10-21 \\
ArticleHistory & $:$ & OnlineDate \\
\hline \hline ArticleCopyright & $:$ & BioMed Central Ltd2002-10-21 \\
\hline \hline ArticleGrants & $:$ & \\
\hline \hline ArticleContext & $:$ & 130593311 \\
\hline \hline
\end{tabular}




\section{Jonathan B Weitzman}

Email: jonathanweitzman@hotmail.com

The tetraspanins form a large family of four-transmembrane-spanning proteins that are involved in a wide range of cellular functions in mammals. In the October 15 Proceedings of the National Academy of Sciences Fradkin et al. describe characterization of tetraspanin expression and functions in Drosophila (Proc Natl Acad Sci USA 2002, 99:13663-13668). The first tetraspanin gene to be identified in flies was Latebloomer $(\mathrm{lbm})$, which is expressed in motoneurons and has been implicated in the formation of synaptic contacts at the neuromuscular junction. Analysis of the Drosophila melanogaster genome sequence revealed the existence of an additional 34 genes encoding tetraspanins. Fradkin et al. performed RNA in situ hybridization analysis of tetraspanin expression during Drosophila development. The genes show very different expression patterns, but fall into three groups that are expressed in the nervous system, the gut or the epidermis. In addition to $l b m$, two other tetraspanins are expressed in motoneurons. Fradkin et al. engineered a deletion of these three tetraspanin genes and observed an increase in the $\mathrm{lbm}$ synaptic phenotype. Analysis of other fly tetraspanins is likely to provide further insights into the function and genetic redundancy of this large gene family.

\section{References}

1. Complexes of tetraspanins with integrins: more than meets the eye.

2. Proceedings of the National Academy of Sciences, [http://www.pnas.org]

3. Genomewide analysis of the Drosophila tetraspanins reveals a subset with similar function in the formation of the embryonic synapse., [http://www.pnas.org/cgi/content/abstract/99/21/13663]

4. A neural tetraspanin, encoded by late bloomer, that facilitates synapse formation. 